\title{
Urgences
}

\section{Sur ma bicyclette}

\section{Michelle Dubois}

Numéro 8, 4e trimestre 1983

Littérature jeunesse

URI : https://id.erudit.org/iderudit/025122ar

DOI : https://doi.org/10.7202/025122ar

Aller au sommaire du numéro

Éditeur(s)

Urgences

ISSN

0226-9554 (imprimé)

1927-3924 (numérique)

Découvrir la revue

Citer ce document

Dubois, M. (1983). Sur ma bicyclette. Urgences, (8), 73-75.

https://doi.org/10.7202/025122ar

Ce document est protégé par la loi sur le droit d'auteur. L'utilisation des services d'Érudit (y compris la reproduction) est assujettie à sa politique d'utilisation que vous pouvez consulter en ligne.

https://apropos.erudit.org/fr/usagers/politique-dutilisation/
Cet article est diffusé et préservé par Érudit.

Érudit est un consortium interuniversitaire sans but lucratif composé de l’Université de Montréal, l'Université Laval et l'Université du Québec à Montréal. Il a pour mission la promotion et la valorisation de la recherche. https://www.erudit.org/fr/ 


\section{MICHËLE DUBOIS}


Sur ma bicyclette

je vole, je m'échappe

le vent me court après

avec ses dix vitesses

je fonce, je pédale, j'avale deux trois nuages

ils coulent dans mes veines

comme un fier carburant

et ronfle le moteur

à la place du coeur

à moi la plaine, à moi la mer,

à moi le ciel et l'univers!

Mais, vlan!

juste un caillou

dessous ma roue...

je suis sur les genoux!

le vent passe en riant...

- Tu verras bien, le vent, je t'aurai!

un jour, je serai grande

et c'est moi qui rirai! 
On est cinq, on est vingt, on est tous très malins.

On connaît par coeur les chemins de la peur,

les mots de la magie, les masques de l'ennui.

On espionne les voisins sous leurs airs quotidiens.

Notre code secret nul autre ne le connaît.

Notre repaire enfoui dans un lieu interdit

C'est là que notre bande conçoit des plans parfaits pour semer l'épouvante ou cerner les suspects.

Si vous cherchez à vivre l'aventure hors des livres faites-nous ce signe discret... mais, chut! c'est un secret! 